\title{
A kulturális javak védelmének rendészeti eszközrendszere Magyarországon
}

\section{LUKÁCS Dalma ${ }^{1}$}

\begin{abstract}
A kulturális javak illegális kereskedelme elleni fellépésben a Nemzeti Nyomozóiroda Múkincsvédelmi alosztálya, valamint a határon állomásozó vámés pénzügyőrök említése releváns. A tanulmány szervezetekről szóló részeinek megírásához az interjúk és a megfigyelés technikája szolgált alapul. A szervezetek bemutatása mellett fontos lenne, hogy mind a civil lakosság, mind a rendörség átessen egy érzékenyítésen, amely a kulturális javak védelmét szolgálja. Ennek érdekében mind oktatási, mint technológiai szinten fejlödnie kell a szervezeteknek.
\end{abstract}

Kulcsszavak: kulturális javak, nyomozás, társadalmi érzékenyítés

\section{Bevezetés}

A kulturális javak rendészeti védelme egyszerre megközelíthető elméleti és gyakorlati szempontból. Ebben a tanulmányban ezekre fókuszálva mutatom be, hogy a mútárgyvédelemben részt vevő Nemzeti Nyomozó Iroda Műkincsvédelmi Alosztálya (a továbbiakban: NNI Múkincsvédelmi Alosztálya), valamint a Nemzeti Adó- és Vámhivatal (a továbbiakban: NAV) milyen feltételekkel múködik jelenleg, valamint hogy milyen szereppel bírnak a kulturális javak illegális kereskedelme elleni fellépésben. Ezen túl, fontos pontnak tartom, hogy a társadalmi érzékenyítést, valamint ennek rendészeti irányú kezdeményezését is bemutassam, hiszen, például ha nem érti az illető, hogy a műtárgylopással a nemzeti értékeket is csorbítja, és azzal sincs tisztában, hogy mikor követ el búntényt ezzel, akkor ott a rendészeti szakembereknek kell fellépniük ellenük. Emellett a tudatos fellépés jele az is, ha a civil lakosság bevonható a rendészeti tevékenységbe, és mind az adatbázist, mind a felderítés és a nyomozás során tudja segíteni a rendészeti szerveket a kulturális javak védelme során.

LUKÁCS Dalma, PhD-hallgató, NKE Rendészettudományi Doktori Iskola

Dalma LUKÁCS, PhD student, National University Of Public Service

https://orcid.org/0000-0001-7051-163X, lukacs.dalma.93@gmail.com 


\section{Nemzeti Nyomozó Iroda - Múkincsvédelmi Alosztály²}

1997-től vette kezdetét a mai Múkincsvédelmi Alosztály első formai megjelenése, amelynek alapja az akkori Múvelődési és Közoktatási Minisztérium, a Belügyminisztérium és az Országos Rendőr-fôkapitányság (a továbbiakban: ORFK) között létrejött együttműködési megállapodás volt. 1998-tól jött létre a Vagyon és Múkincsvédelmi Alosztály, ahol már a kulturális javak védelme került a központba. A jelenlegi nevét 2004-ben nyerte el, amikor Múkincsvédelmi Alosztállyá formálódott a Nemzeti Nyomozóirodán belül, ahol folytatta korábbi munkáját. Az alosztály létszáma nem éri el a tíz fôtt.

A szervezet feladata, hogy a kulturális javakkal kapcsolatos bünüldözési feladatokat ellássa, amely a felderítést és a nyomozást is magában foglalja. Fel kell tenni azt a kérdést, hogy az alapinformációk alapján felmerül-e bủncselekmény gyanúja. Ennek érdekében a nyomozást különböző módszerekkel végzik, és két szakaszra tagolják. Ez a két folyamat nagyon egyszerúen különül el. Az első a felderítés, amely onnantól veszi kezdetét, hogy felmerül a gyanú. Az első fázisban nem ismert az elkövető, itt még az adatok összegyújtése folyik, különböző nyomozati cselekmények elvégzésére kerül sor (például helyszíni szemle, tanúkihallgatások, továbbá a körözés elrendelése stb.). A második fázisban már körvonalazódik, hogy ki lehet a gyanúsított. Itt válik kiemelkedővé a bizonyítási eljárás és a kivizsgálás folyamata. Következő eleme a második fázisnak a bizonyítási eljárás. Ha sikeresen azonosították az elkövetőt, akkor vádemelési javaslatot tesznek az ügyészségnek, és az ügy a Múkincsvédelmi Alosztály számára lezárul. Innentől kezdve az ügyészség kezébe kerülnek az esetek, ahol már megtörténik a vádemelés.

A nyomozó hatóság feladata a kulturális javakkal kapcsolatos kiemelt bűncselekmények felderítése, nyomozása és a bủncselekmények során eltünt kulturális javak felkutatása. Ez azonban nem kizárólagos hatásköre a Múkincsvédelmi Alosztálynak. Nyomozás a mútárgyak kapcsán indulhat a megyei fôkapitányságokon és kapitányságokon egyaránt. Ebből a szempontból meghatározó lehet az alacsony, illetve a magas kár értékủ bűncselekmény. Az évekkel később előkerült, a büncselekményekhez köthető mútárgyakkal is a Múkincsvédelmi Alosztály foglalkozik, valamint az orgazdasággal és a kulturális javakat érintő más visszaélésekkel is egyaránt.

Ezek mellett a lakossági tájékoztatásban szórólapon és a médián keresztül is megjelennek, amelyben a magángyüjtők leltárkészítésének fontosságát emelik ki. Ezek mellett együttmúködnek az ORFK-val, Nemzetközi Búnügyi Együttmúködési Központtal (a továbbiakban: NEBEK), a hazai és a külföldi társszervekkel, valamint szakirányú képzésekben is részt vesznek. Ezenfelül támogatják a diákokat, hiszen az oktatásban és a szakdolgozatok készítésénél is segédkeznek, valamint több kutatásban és projektben is részt vesznek, mint például a Közigazgatás- és Közszolgáltatás-fejlesztési Operatív Program (a továbbiakban: KÖFOP), valamint a Hamisítás Elleni Nemzeti Társulat (a továbbiakban: HENT) külsős tanácsadójaként. 2012-ben pályázatukkal elnyertek

2 Köszönet a szakembereknek a szíves szóbeli közlésért. 
egy európai uniós támogatást, amely pályázat keretén belül többek között kiállítást, nemzetközi konferenciát, a rendőrkollégák részére továbbképzést, valamint internetes felületen játékot szerveztek. Mindezt annak érdekében, hogy hangsúlyozzák a kulturális javak fokozottabb védelmének fontosságát, és növeljék az erre a célra fordítható erőforrásokból nyerhető kapacitást.

Az alosztályon csak hivatásos rendőrök dolgoznak, viszont nem kötelező rendelkezniük bármilyen művészeti végzettséggel, hiszen bármennyire előnyös is, mégsem az ő feladatuk, hogy azonosítsák a tárgyakat. Erre igazságügyi szakértőket kérnek fel. Nem titkolt céljuk, hogy egy speciális lopott tárgyak adatbázisával rendelkezzenek, hiszen Európa más országaiban is létezik ilyen a kulturális javak védelmével foglalkozó rendvédelmi szervezeti egységeknél, amely a nyomozás előmenetelét is megkönnyíti.

Nyomozásoknál fontos a kárérték nagysága, hiszen ez minősíti a bűncselekményt. Alapvetően ez határozza meg, hogy kik folytathatnak nyomozást az adott tárgy kapcsán (a NNI speciális alosztálya vagy a főosztályok). Szakértő állapítja meg, hogy milyen nagyságú kárértéket képvisel az adott tárgy. Ezenkívül a szakértők feladata azért is nagyon fontos, mert meg kell állapítaniuk, hogy az adott tárgy eredeti-e. Erre egyes esetben más anyagvizsgálati módszereket is igénybe vehetnek.

A múkincsvédelmi nyomozók ezenkívül jó kapcsolatot ápolnak a múzeumokkal és a galériatulajdonosokkal. Ez a kölcsönös kapcsolat több szempontból is értékes, hiszen a rendőrség az aukciós házakat és a galériatulajdonosokat is tudja értesíteni egy-egy lopás esetén, így ha ott próbálnák az adott árut eladni, jelezhetnek a NNI-nek. Fordítva pedig fontos, hogy a rendőrség ismerje, hogy mi az aktuális „trend”, milyen mútárgyak azok, amik a legkelendőbbek az adott időpontban és ezt az információt a galériatulajdonosok és az aukciós házak munkatársaitól érik el.

A bűncselekménytípusok közül a kulturális javak kapcsán a legrelevánsabb az orgazdaság, ${ }^{3}$ lopás, sikkasztás, ${ }^{4}$ rongálás ${ }^{5}$ és a szerzői jogok megsértése. ${ }^{6}$ A jogtalan elsajátítás ${ }^{7}$ alatt azt értjük, amikor az ember például a szántóföldön véletlenül talál egy ókori érmét és zsebre rakja, illetve nyolc napon belül nem szolgáltatja be. Azonban, ha már fémkeresővel célirányosan kutatja azt vagy más régészeti leletet, és úgy szerzi meg, akkor a tette lopásnak ${ }^{8}$ minősül.

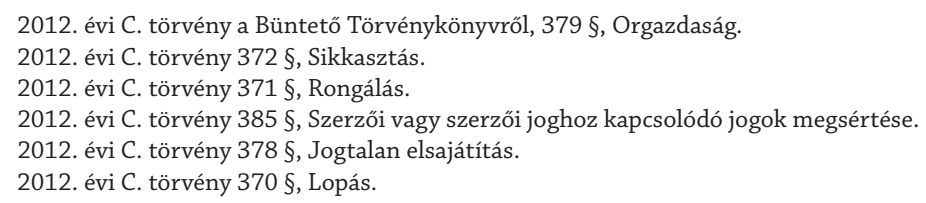




\section{Nemzeti Adó- és Vámhivatal}

Az Adó- és Pénzügyi Ellenőrzési Hivatal (a továbbiakban: APEH) és a Vám- és Pénzügyőrség (a továbbiakban: VP) összeolvadásából jött létre a NAV. Fontos feladatot lát el, hiszen a határszakaszon behozott árukat ők vizsgálják át, így az illegális be- és kihozatal ellenőrzésében, kiszűrésében fontos szerepük van. Ezek mellett a mélységi ellenőrzések is lényeges pontok, amelyeket a NAV központi rendészeti főosztály irányítása alatt hajtanak végre. A mélységi ellenőrzés fontosságára jó példa a 2016 őszén Kecskemét mellett az autópályán megállított kamion, amelyben több mint száz mütárgyat találtak. ${ }^{9}$

Kulturális javak kapcsán nincs saját adatbázisuk, csupán a Miniszterelnökségnél lévő adatbázisból az aktuális ügyeknél megosztott információkból tudtak egyet készíteni, ám ez nem teljes, és függ a Forster Központ jogutódjának információközzétételétől. Ha szakértőt kell kihívni, akkor szintén a Miniszterelnökséggel lépnek kapcsolatba. A feladatköre a felderítésnél megáll, utána a rendőrségnek adják át az ügyet.

A kulturális javak kapcsán oktatásban nem részesülnek, azonban a szervezet munkatársai a Nemzeti Közszolgálati Egyetem Rendészettudományi Karán található Vámés Pénzügyőr tanszéken előadásokat tartanak többek között kettős felhasználású tárgyakból, ${ }^{10}$ amelyeknél részben érintik a témát.

\section{Ellenörzés a határon}

Az illegális kereskedelem megfékezésében nagyon fontos szerepet játszanak a schengeni külső határok és az ott fellelhető ellenőrzési lehetőségek. ${ }^{11}$ Magyarország kiemelt jelentőséggel bír, hiszen a schengeni térség határországa, feladata pedig azért is fontos, mert ha egy tárgy bejut a határon illegálisan, akkor Európán belül a szabad kereskedelem jogán, már nem valószínű, hogy megtalálják. ${ }^{12}$ Ezért is lényeges megvizsgálni, hogy pontosan kik és milyen módszerekkel végzik a határellenőrzést. Az áruk, így a mútárgyak vámellenőrzése a határon nem a rendőrök, hanem a Nemzeti Adó- és Vámhivatal (NAV) munkatársainak feladata. A jogszabály szerint a NAV feladatai közé tartozik többek között:

- azok az ellenőrzési és felügyeleti feladatok, amelyeknek célja a pénzmosás és a terrorizmus finanszírozásának megelőzése, illetve megakadályozása; ${ }^{13}$

- a vámeljárásokhoz és tartozásokhoz kapcsolódó érték meghatározása és kiszabása mellett a vámhatáron történő áru- és utasforgalom vámellenőrzése; ${ }^{14}$

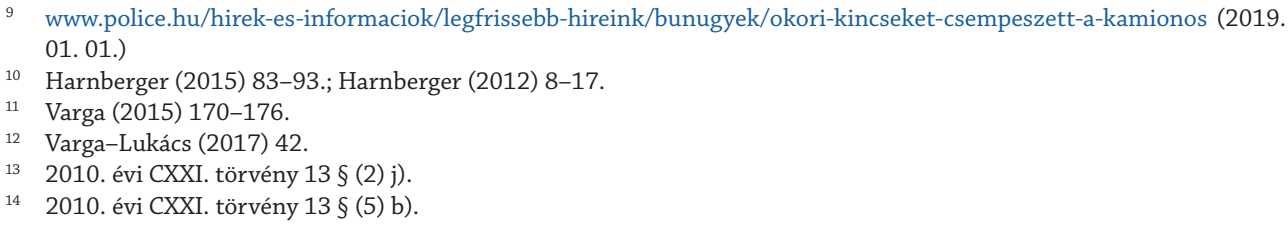


- „közvetlenül vagy közvetve - meghatározott körben - az áruk azonosságának (adózási szempontból történő besorolásának és egyéb jogszabály által meghatározott követelményeknek) a vizsgálatát, illetve a vizsgálat megtörténtének ellenőrzése". ${ }^{15}$

A rendőrök, illetve a pénzügyőrök minden gépjármútípusnál máshogy járnak el a vizsgálat során. A buszokat egy megállásos ellenőrzésnek vetik alá, ahol a rendőrök és a vámosok egyszerre ellenőrzik a járműveket. A szakemberek kockázatelemzés alapján eldönthetik, hogy csak egy csomagot vizsgálnak-e át vagy többet. Továbbá lehetőség van üregvizsgáló berendezés használatára is. A tehergépjármủ ellenőrzésénél a rendőrök vizsgálják át először az utasteret, továbbá a rakteret. Ha mindent rendben találtak, akkor a pénzügyőrök következnek, akik más szempont szerint kutatják át a rakományt, illetve míg a rendőröknek a személy, okmány és gépjármú áll a fókuszukban, addig a NAV szakemberei az adóhoz köthető ellenőrzéseket hajtják végre, továbbá ellenőrzik, hogy nem szállít-e az illető csempészett árut. Ennél az ellenőrzési pontnál következik a mérlegelés, amikor is a bruttó tömegből kimérik a nettót, majd leellenőrzik, hogy az okmányokban mekkora tömeg szerepel. Ennek a mérésnek többek között azért is nagy a jelentősége, mert nagy összsúly esetén a jármú tengelye megsérülhet, így ebben az esetben nem engedik tovább a járművet. A tehergépjármúveket röntgenvizsgálatnak is alávetik minden esetben. A személygépjármú, továbbá busz esetében ritkán alkalmazzák ezt a módszert, ami meghatározza a csempészet módszerét is, ám erről később ejtek szót. Az utasfülkét szakemberek vizsgálják át és csak a rakteret vetik alá a röntgensugárzásnak. Abban az esetben, ha az eszköz meghibásodik, esetleg vihar következik be, a szakemberek veszik szemügyre az árukat, illetve a rakteret is. A röntgenellenőrzés két fázisból áll: az elsőnél kép készül a járműről és a forgalmi rendszám alapján egy egyedi azonosítót kap a gépjármủ. Ezután jelzésre elindulhat a tehergépjármű maximum 5 kilométer per órás sebességgel, hogy elkészítsék a felvételt. A második fázis az elemzés, ahol a rakodótér röntgenfelvételét elemzik. Itt a különböző színskálák segítségével az átvilágított jármúvet vizsgálják, hogy tartalmaz-e csempészett árut vagy személyt. A módszer annyira sikeres, hogy még az áruval felpakolt tárgyak között, a kerékben, illetve egyéb alkatrészben is megtalálják a szakemberek az elrejtett holmikat. Az adatokat nyolc évig tárolják a rendszerben, ezenfelül negyedévente fórumon tárgyalják meg a módszerrel kapcsolatos tapasztalataikat. Ezenkívül a szomszédos országok is használják a röntgent, így a kétszeres átvilágításon a schengeni határszakaszt átlépve sokkal nagyobb arányban szürik ki a csempészett árukat.

A felsorolt ellenőrzési formák mellett a kockázatelemzés is fontos szerepet tölt be. Ennek a módszernek az a lényege, hogy ne szúrópróbaszerúen, hanem tematikusan, előre meghatározott módon emeljék ki ellenőrzésre a járműveket, hiszen a gördülékenyebb utasforgalom áramlása érdekében nem tudnak mindenkit tüzetesen ellenőrizni.

15 2010. évi CXXI. törvény 13 § (5) c). 
Természetesen ez a módszer sem nyújt 100\%-os megelőzést a bűnözés ellen, azonban csökkentheti a tévedés esélyét. ${ }^{16}$

\section{Felderités menete}

Ha a pénzügyőr úgy véli, hogy szeretne másodlagos ellenőrzést is végezni, akkor az utast egy erre a célra létrehozott helyre irányítja a gépjármúvével. Itt történik magának a járműnek, illetve a csomagoknak az átvizsgálása. Abban az esetben, ha be nem jelentett vámköteles áru, tiltott áru vagy a kulturális javak körébe tartozó tárgy birtokában van az utas, akkor a vizsgálatot végző szakember lefoglalja azt, valamint dokumentálja, amely magában foglalja a fénykép készítését is. A kapcsolattartás minden kulturális javakkal történő bűncselekmény esetén a Miniszterelnökség Örökségvédelmi Hatósági Főosztályán keresztül történik.

A kulturális javak tekintetében minden esetben szakértői véleményt kérnek. Igénybe vehetik a helyi muzeális és kulturális javak szakértőit, akik a Nemzeti Erőforrás Minisztérium (a továbbiakban: NEFMI) rendelet 2. mellékletében feltüntetett intézmények munkatársai. ${ }^{17}$ A gördülékeny munka érdekében fényképet küldenek az egyes szakértőknek, akik azonosítják a tárgyakat. Az azonosítás változó ideig tarthat, hiszen a lefoglalt tárgyegyüttesek mennyisége is más és más. Az értékelésben feltüntetik az egyes darabok leírását, datálását, továbbá az értékét. A tárgyakat bủnjelezik és felkerülnek egy elektronikus bűnjelnyilvántartásba (EBR), majd a büntetőeljárásban történő átfoglalásig a helyi kirendeltségen fellelhető páncélszekrényben tárolják. Amint átkerülnek a tárgyak az illetékes nyomozó hatósághoz, onnantól kezdve az elévülés nem a határszakaszon dolgozó NAV-szakemberek feladata. A tárgyakat leggyakrabban a Szépművészeti Múzeum veszi át, amelyeket átadás-átvételi szerződéssel erősítenek meg.

\section{Csempészési módszerek}

A kulturális javak csempészésénél figyelembe kell vennünk azt a tényezőt, hogy minél jobb állapotban van a tárgy, annál nagyobb a piaci értéke. Bár a megrendelő, illetve a láncolat pár szereplője ezzel tisztában van az esetek nagy százalékában, azonban a szállító (csempész) nem feltétlenül. Ugyanakkor az is megállapítható, hogy elrejtéssel próbálják átcsempészni a tárgyakat, ami jelentheti a gépjármúvek gyári, illetve házilag kialakított üregeiben, esetleg a csomagok közötti rejtést is. A teherautók röntgenezése miatt a buszokat és a személygépjárműveket jobban preferálják a csempészek, ugyanis kisebb a rizikófaktora a lebukásnak. A csempészmódszerek között szerepel a zokniba és egyéb ruhadarabokba, valamint szigetelőszalaggal körberagasztott zacskóba csomagolt megoldás. Előfordul azonban, hogy az ülés alá vagy mögé helyezik csomagolás

\footnotetext{
Csonka-Gulyás-Tornyai (2009) 315.

17 14/2010. (XI. 25.) NEFMI rendelet.
} 
nélkül a mütárgyat, amely eseteknél nincsenek tisztában a tárgy értékével vagy azzal, hogy bűncselekményt követnek el a tárgyak engedély nélküli külföldre szállításával.

A tárgyak forrás- és célországát az elkövetők elmondása alapján tudják beazonosítani, illetve a szakértői véleményből, hogy az adott tárgy honnan eredhet. Ez a kulturális javak csempészútvonalának általános meghatározásához is hozzásegíthet, illetve a tárgyak eredeti tulajdonosához, esetleg lehetővé teszi a múzeumhoz való visszajuttatását a beazonosítással. A határátkelőhelyen állományban lévő pénzügyőrök elmondása szerint nem próbálkoztak az elkövetők mútárgyakhoz kapcsolódó hamis dokumentummal ugyanis a felderített kulturális javakhoz nem szokott az utas semmiféle okmányt vagy papírt felmutatni.

Milyen tárgyak azok, amelyek a leginkább fenyegetettek? A schengeni határ magyarországi szakaszán felderített tárgyak leggyakrabban római kori, illetve bizánci érmék, fibulák, kisebb szobrok, edények, továbbá festmények lehetnek. De ezen túl a nemzetközi illegális piacon a régészeti leletek és festmények (mind eredeti, mind hamisítvány) mellett a vallási kegytárgyak is felfedezhetők. Ezen tárgyak eltulajdonítása egyszerű, hiszen a legtöbb esetben a templomok mindenki előtt nyitva állnak és ellenőrzés nélkül érkezhetünk, valamint távozhatunk a helyszínről. Ezt kihasználva számos kehely, szenttárgy, szobor, valamint freskó és oromzati dísz is áldozatul eshet az illegális kereskedelemnek. A lopott tárgyakból adatbázist készítenek az egyes országok, amelyek közül az Interpol adatbázisa a Works of Art, ${ }^{18}$ valamint az olasz Carabinieri TPC Leonardo ${ }^{19}$ nevezetû adatbázisa a legismertebb. Mint már említettem, sajnos Magyarországon a rendőrség még nem rendelkezik ezen adatbázissal a kezdeményezések ellenére sem. A Leonardo-adatbázis vizsgálata alapján, valamint az olaszok által évenkénti kiadott tanulmányokból és katalógusokból ${ }^{20}$ ismerjük meg, hogy mely tárgyak azok, amelyek Olaszországban a legkelendőbbek. Az Interpol adatbázisa az egy országra kiterjedő adatokkal ellentétben a nemzetközi körözésben megjelenő mútárgyakat foglalja össze. Ezen adatbázisoknak létezik civil felhasználású, valamint „titkosított” része is, amelyet csak az adatkezelő, valamint az adott szervezett láthat. ${ }^{21}$

\section{A társadalmi érzékenyítés jelentősége a kulturális javak védelme terén}

A hazai fegyveres szervek bemutatása mellett szükséges a kulturális javak védelmének kicsit elméletibb oldalával is foglalkozni, mint például a társadalmi érzékenyítés szerepével. A társadalmi érzékenyítés elengedhetetlen szerepe a kulturális javak védelmének. Ha úgy tetszik, ez az első lépcsőfok. Az alapoknál kezdve: az emberekben tudatosítani kell, hogy a kultúra fontos. Mind eszmei, szellemi értéke, mind a nemzeti identitás és a világban való hovatartozásunk szempontjából. Enélkül nem érti meg az ember,

\footnotetext{
18 Interpol WOA adatbázisa: https://www.interpol.int/notice/search/woa (2017. 12. 29.)

19 Carabinieri TPC adatbázisa: http://tpcweb.carabinieri.it/SitoPubblico/search (2017. 12. 29.)

20 La Guardia di Finanza (2003); La Guardia di Finanza (2016)

21 Lukács (2019)
} 
hogy miért is fontos a tárgyak védelme, hiszen ha ellop egy mútárgyat, azzal a nemzetet is egyaránt megkárosítja.

\section{Hogyan érzékenyítsük a civil szférát?}

A leghatékonyabban akkor járnánk el, ha már gyermekkorban megkezdődne az érzékenyítés. Ez a tevékenység főleg oktatást foglal magában és ismeretterjesztést. Olaszországban a Carabinieri TPC 22 általános és középiskolában oktatást végez a kulturális javak védelmét tekintve. A Nemzeti Nyomozó Iroda Múkincsvédelmi Alosztálya egy 2012-es európai uniós pályázat keretein belül például a gyerekek számára készített játékot a kulturális javak dokumentálásáról, ezen belül is a házi dokumentációról, azonban sajnos ez csupán egy évig volt elérhető, a pályázat keretein belül.

\section{$A$ rendöri szféra érzékenyitése}

Az eddigi kutatásom során azt vettem észre, hogy a magyar rendészeti szervek viszonyulása és érdekeltsége a kulturális javakhoz igencsak csekély. Az interjúk során kiderült, hogy a képzésük alatt oktatást, valamint továbbképzést nem, vagy csak minimális esetben kapnak kulturális javakra vonatkozóan, így nincsenek is tisztában a téma fontosságával. Sok esetben ez természetesen visszavezethető a civil szféra tudatosításának a hiányára is, hiszen gyerekkorban sem kapták meg már az általános iskolában a szükséges hátteret hozzá. A rendőri szféra érzékenyítése tehát gyermekkorban a civil szféra érzékenyítésénél kezdődne, majd oktatással és különböző képzésekkel folytatódna az állományba lépés során. Ha a rendőrségnek lenne lehetősége oktatás keretein belül érzékenyíteni a civil szférát, önmaguk is jobban felkészültebbek és elkötelezettebbek lennének a téma iránt.

\section{A rendöri szféra társadalmi érzékenyítése}

Olaszországban a Carabinieri TPC munkatársai a felderített múkincsekből gyakran kiállításokat szerveznek. Ez azért is nagyon fontos, mert Magyarországon eddig kettő ilyen készült az (Al)világot járt múkincsek címú kiállítás 2006. március 23. - május 28. között, amelyet Kulturális Örökségvédelmi Hivatal rendezett (ORFK, VPOP, KÖH), ${ }^{23}$ valamint 2012-ben a Szépmúvészeti Múzeum kooperációjával. A kiállítás nagy népszerűségnek örvendett, azonban azóta sem történt hasonló szervezés. Olaszországban évente többször készítenek felderített műkincsekkel kiállításokat, valamint sajtótájékoztatót és évente egyszer könyvet is adnak ki az aktuális évi felderített mútárgyakról. Ezenfelül a Carabinieri már egy applikációt is használ, amellyel nemcsak a saját munkájukat könnyítik meg, de a civil szféra számára is elérhetőbbé és érthetőbbé teszik

\footnotetext{
Olasz mútárgyvédelmi egység a Carabinierin belül.

Jelenlegi megfelelói a szervezeteknek: NNI; készenléti rendőrség, ORFK; NAV; Forster Gyula központ jogutódjai.
} 
a téma fontosságát. Ez az applikáció az iTPC, amely a Leonardo-adatbázisból készített közösségi felhasználású verzió.

\section{A „social media” bevonása az illegális múkincskereskedelem elleni fellépésbe Magyarországon}

Véleményem szerint a közösségi média ${ }^{24}$ egy kiaknázatlan terület a kulturális javak védelme tekintetében. Azonban ez a felület elengedhetetlen manapság, hogy akár a fiatalabb, akár az idősebb generációhoz eljusson a mondanivalónk.

A média hatására nagyon jó példa az ISIS általi iraki múzeumok kifosztása és az amerikaiak mozgalma a mútárgykereskedelem szempontjából. Amíg a médiában nem jelent meg, hogy a múzeumokat kifosztják, addig az amerikai katonák nem intézkedtek, hiába kértek tőlük segítséget az emberek. Ezzel ellentétben, amint a médiában megjelent a valóság, az amerikaiak kényszerhelyzetbe kerültek és nekiálltak a tárgyak felderítésének és visszaszerzésének. Természetesen még több ezer tárgy van, amelyek a 2003-as támadások alatt az Iraki Nemzeti Múzeumból lettek eltulajdonítva és jelenleg nem ismerjük a tartózkodási helyzetüket, de a példa alapján láthatjuk, hogy a médiának óriási befolyásoló ereje is van.

A közösségi média olyan felület, amellyel sokszor olyan rétege is elérhető a társadalomnak, amely a hagyományos médiafelületekkel nem.

A social media a tradicionális média mellett szintén nagy befolyásoló erővel bír, hiszen manapság már nagyon kevés azon emberek száma, akik nem rendelkeznek legalább egy felülettel. Ahogy az olaszok is el tudják érni a civil lakosságot az internetes újítások segítségével, úgy hazánkban is lenne rá lehetőség, azonban különböző kritériumok mellett!

Amíg maga a rendőrség nem esett át a téma iránti érzékenyítésen, addig nem lehet hatékony az intézkedésük ezen a területen.

- Rendelkezni kell a rendőrségnek egy informatikusokból és szakértőkből álló csoporttal, akik kezelik az adott felületet és folyamatos újdonságokat, valamint friss híreket és újításokat tárnak a civil lakosság felé.

- Fontos, hogy a rendőrség által alkalmazott oktatás során (diákoknál) már az adott applikációt is bemutassák, így a civilek azonnal megtanulják használni.

- Fel kell mérni a külföldön jól múködő módszereket, és ha azok alkalmazhatóak lennének a magyar közönség felé, akkor adoptálni azokat.

- Közelebb kell hozni a civileket a kulturális javak védelméhez, ezért a felderített tárgyakat és azok tulajdonságait is meg lehetne jeleníteni az alkalmazásban, valamint játékos feladatokkal egy-egy felderítést ők maguk végezhetnének el virtuálisan.

\footnotetext{
24 A social media vagy közösségi média, amely alatt a Facebook, Instagram, Twitter és különböző internetes portálokat, valamint applikációkat érthetjük.
} 
A social media különböző felületein ezenkívül vitaindító kérdéseket is fel lehetne tüntetni, valamint a nyomozásban való segítség kérésére is ez lehetne a leggyorsabb felület.

\section{Konklúzió}

A folyamatos szervezeti átalakulások negatív hatással vannak az egyes szervek egymás közötti kommunikációjára. Azonban, ezen túl a saját eszközeiket kihasználva az a kevés magyar szakember, aki ezzel a területtel behatóbban foglalkozik, mindent megtesz, hogy a kulturális javakat megvédje. Ahogy korábban is említettem, a kulturális javak védelme az állam szemszögéből tekintve nem élvez prioritást, hiszen bevétel nem származik belőle. Azonban ezen lehetne változtatni, hiszen a hazai turizmus is megindulhatna, emellett a nemzeti öntudat és az eszmei értékek iránti vágy fokozása is fellendülhetne. Ezt elsősorban a társadalmi érzékenyítésben, oktatásban és a technológiai fejlesztésekben kellene keresni.

\section{IRODALOMJEGYZÉK}

Csonka Károly - Gulyás Zsolt - Tornyai Miklós (2009): Határrendészeti kockázatelemzés alapelvei. Pécsi Határör Tudományos Közlemények X. Tanulmányok A rendészet kultúrája-kulturált rendészet címú tudományos konferenciáról. 315-330.

Harnberger György (2015): A kettős felhasználású termékek vámhatósági ellenőrzése. In Szabó Andrea - Zsámbokiné Ficsovszky Ágnes szerk.: Az adó- és vámszolgálatok aktuális kihivásai. Konferencia és tanulmánykötet. 83-93. Forrás: https://rtk.uni-nke.hu/document/rtk-uni-nke-hu/azado-es-vamszolgalatok-aktualis-kihivasai.original.pdf (2019. 01. 01.)

Harnberger György (2012): Kettős felhasználású termékek és technológiák. Vám-Zoll. 8-17.

La Guardia di Finanza (2003): L'Arte Ritrovata. A tutela dei Beni Culturali. Roma, Academia Internazionale ARCO.

La Guardia di Finaza (2016): Symposium: a tavola tra mito e cultura. Roma, Recuperi archeologici della Guardia di Finanza.

Lukács Dalma (2019): A kulturális javak védelmére alkalmazott olasz rendészeti eszközrendszer, különös tekintettel az adatbázisokra és a tömegtájékoztatásra. Ordinem Facere, kézirat.

Varga János - Lukács Dalma (2017): A schengeni információs rendszer lehetőségei az illegális műkincs kereskedelem elleni fellépésben. Határrendészeti Tanulmányok, 14. évf. 1. sz. 42-52.

Varga János (2015): Az Integrált Határigazgatás európai uniós rendszere. Hadtudományi Szemle, 8. évf. 3. sz. 170-176.

\section{Jogforrások}

14/2010. (XI. 25.) NEFMI rendelet a kulturális javak kiviteli engedélyezéséről.

2012. évi C. törvény a Büntető Törvénykönyvről.

2010. évi CXXI. törvény az ügyészségi szolgálati viszonyról és az ügyészségi adatkezelésről szóló 1994. évi LXXX. törvény módosításáról. 


\section{Internetes források}

Carabinieri TPC adatbázisa: http://tpcweb.carabinieri.it/SitoPubblico/search (2017. 12. 29.)

Interpol WOA adatbázisa: www.interpol.int/notice/search/woa (2017. 12. 29.)

www.police.hu/hirek-es-informaciok/legfrissebb-hireink/bunugyek/okori-kincseket-csempeszett-akamionos (2019. 01. 01.)

\section{ABSTRACT \\ The Law Enforcement Tools for the Protection of Cultural Properties in Hungary LUKÁCS Dalma}

The purpose of this research is to identify how the Hungarian agencies fight against the illicit trade of cultural properties. The National Bureau of Investigation and the Border Tax and Customs guardians are important to mention in this field. The research was based on the method of observation and interviews. In addition to presenting agencies, it would be important for both the civilian population and the police to undergo a sensitisation, which serves to protect cultural property. To achieve that, the agencies should develop themselves both on an educational and technological level.

Keywords: cultural property, investigation, social sensitisation 